\title{
How the fluctuations of water levels affect populations of invasive bivalve Corbicula fluminea (Müller, 1774) in a Neotropical reservoir?
}

\author{
Paschoal, LRP. ${ }^{a b *}$, Andrade, DP. ${ }^{a}$ and Darrigran, G. $^{c}$ \\ ${ }^{a}$ Laboratório de Hidrobiologia, Departamento de Ciências Biológicas, Fundação de Ensino Superior de Passos - FESP, \\ Universidade do Estado de Minas Gerais - UEMG, Rua Sabará, 164, CEP 37900-106, Passos, MG, Brazil \\ 'Invertebrate Morphology Laboratory - IML, Departamento de Biologia Aplicada, Universidade Estadual \\ Paulista - UNESP, Via de Acesso Prof. Paulo Donato Castellane, s/n, CEP 14884-900, Jaboticabal, SP, Brazil \\ ${ }^{\mathrm{c}}$ Consejo Nacional de Investigaciones Científicas y Técnicas - CONICET, Grupo de Investigación de Moluscos Invasores/ \\ Plagas - GIMIP, División Zoología Invertebrados, Museo de La Plata - FCNyM-UNLP, Paseo del Bosque, \\ s/n, La Plata, 1900, Buenos Aires, Argentina \\ *e-mail: lucasrezende20@gmail.com
}

Received: June 4, 2013 - Accepted: October 7, 2013 - Distributed: March 31, 2015

(With 6 figures)

\begin{abstract}
Corbicula fluminea is an invasive bivalve responsible for several environmental and financial problems around the globe. Despite the invasive potential of this species, it suffers certain restrictions in lentic environments due to natural phenomena that significantly affect its population structure (e.g. water column fluctuation and sunlight exposure). The present study addresses how temporal decline of the water level in a Neotropical reservoir and exposure to sunlight affect the population structure of $C$. fluminea. Samplings were carried out twice in the reservoir of Furnas Hydroelectric Power Station (HPS) (Minas Gerais, Brazil), in 2011 and 2012. Population density, spatial distribution and mean shell length of $C$. fluminea were estimated for each year after sampling in 51 quadrats $\left(0.0625 \mathrm{~m}^{2}\right)$ placed on three transects at different distances along the reservoir margins (0,10 and $20 \mathrm{~m}$ from a fixed-point). We observed a predominance of $C$. fluminea in both years, with a simultaneous gradual decrease in density and richness of native species in the sampling area. Significant differences in density of $C$. fluminea were registered at different distances from the margin, and are related to the temporal variability of physical conditions of the sediment and water in these environments. We also registered a trend toward an increase in the density and aggregation of $C$. fluminea as we moved away from the margin, due to the greater stability of these areas $(>10 \mathrm{~m})$. The mean shell length of $C$. fluminea showed significant difference between the distinct distances from the margin and during the years, as well as the interaction of these factors (Distances $v s$. Years). These results were associated with the reproductive and invasive capacity of this species. This study reveals that these temporal events (especially water column fluctuation) may cause alterations in density, spatial distribution and mean shell length of $C$. fluminea and the composition of the native malacofauna in Neotropical lentic environments.
\end{abstract}

Keywords: non-native species, desiccation, water column levels, ecological aspects, Furnas HPS reservoir.

\section{Como a flutuação dos níveis da água afetam as populações do bivalve invasor Corbicula fluminea (Müller, 1774) em um reservatório neotropical?}

\begin{abstract}
Resumo
Corbicula fluminea é um bivalve invasor, responsável por inúmeros problemas ambientais e econômicos ao redor do mundo. Apesar de sua capacidade de invasão, a espécie sofre certas restrições devido a fenômenos naturais em ambientes lênticos, afetando significativamente sua estrutura populacional (e.g. flutuação do nível da água e a exposição à luz solar). O presente trabalho avaliou como o decréscimo temporal do nível da água de um reservatório neotropical e a exposição solar, afeta a estrutura populacional de C. fluminea. Duas amostragens foram realizadas no reservatório da Usina Hidrelétrica (UHE) de Furnas (Minas Gerais, Brasil), em 2011 e 2012. A densidade populacional, o comprimento médio e a distribuição espacial da espécie para cada ano foram estimados após amostragem em 51 quadrats $\left(0,0625 \mathrm{~m}^{2}\right)$ dispostos em três transectos em diferentes distâncias das margens do reservatório $(0,10$ e $20 \mathrm{~m}$ em relação a um ponto fixo). Observou-se o predomínio de C. fluminea em ambos os anos, coincidindo com o decréscimo da densidade e riqueza de espécies nativas nas áreas de amostragem. Foram registradas diferenças significativas na densidade de $C$. fluminea entre as distâncias da margem, sendo atribuídas principalmente à variabilidade temporal do substrato e da água desses ambientes. Registrou-se também uma tendência em aumento da densidade e agregação com o aumento da distância
\end{abstract}


da margem, devido à maior estabilidade dessas áreas $(>10 \mathrm{~m})$. Houveram diferenças significativas no tamanho médio das conchas de $C$. fluminea entre às distâncias da margem e durante os anos, assim como na interação desses fatores (Distâncias vs. Anos). Tais resultados foram associados à capacidade reprodutiva e invasiva da espécie. Esse estudo revelou que eventos temporais (principalmente, a flutuação do nível da água) em ambientes lênticos neotropicais provocam alterações na densidade, tamanho médio e distribuição de $C$. fluminea e na composição da malacofauna nativa.

Palavras-chave: espécie não-nativa, dessecação, nível da coluna de água, aspectos ecológicos, reservatório UHE Furnas.

\section{Introduction}

Reservoirs are artificial man-made environments and are considered intermediary water bodies because they depend on water detention time and variation between storage and discharge of water (Tundisi et al., 2008). These impoundments are mainly employed for power production, but serve other purposes, such as water sources for irrigation, sources of income and leisure. After implementation, water quality in reservoirs is usually compromised due to eutrophication and other negative effects brought upon by human presence and activity in the surrounding areas, leading to alterations on nutritional load and faunal composition (Andrade et al., 2012).

Molluscs are among the main aquatic organism groups affected by this process. Generally, mollusc populations present high densities and consequently significant biomass (Mansur et al., 2003; Santos et al., 2012). They are frequently used as biomonitors, because in addition to being sensitive to pollution and eutrophication, they are capable of accumulating several pollutants found in aquatic environments (Darrigran, 1999; Furley and Oliveira Filho, 2000). Molluses also play an important role in organic matter cycling in aquatic ecosystems (Darrigran and Lagreca, 2005; Vaughn, 2010).

In the current global scenario, the non-native bivalve Corbicula fluminea (Müller, 1774) is markedly responsible for a wide range of environmental and financial problems involving reservoirs and hydroelectric plants in several parts of the world (Santos et al., 2012; Paschoal et al., 2013a). This species is restricted to freshwater environments and its shell length varies from 10 to $60 \mathrm{~mm}$. Its populations present an aggregate distribution and consequently had high densities and biomass. Corbicula fluminea is considered an invasive and transforming species (Sousa et al., 2009; Santos et al., 2012).

Despite the ecologic and economic impacts stemming from the invasions, populations of $C$. fluminea inhabiting lentic environments - especially reservoirs - are submitted to certain environmental restrictions due to damming, which significantly affect their population structure. In addition to anthropic impacts, certain hydrological and natural phenomena, such as the deposition of particulate matter, the action of waves on the margins and water column fluctuation occur irregularly in time and space and may cause instability in the benthic communities in reservoirs.

Water level fluctuations and exposure to sunlight are the main factors responsible for desiccation of molluscs, and directly affect bivalve populations. Darrigran (1999), Darrigran and Lopez-Armengol (1998) and Darrigran and
Lagreca (2005) stated that several species of freshwater molluscs are capable of surviving to temporal and spatial desiccation by hibernating or migrating to deeper or more humid areas. Recently, however, Sousa et al. (2012) and Paschoal et al. (2013a) recorded the significant mortality of $C$. fluminea and other molluscs caused by desiccation, when large densities and biomass of individuals were transported and remained near the river margins.

The present study is aimed at evaluating how temporal decline of the water level in a Neotropical reservoir and exposure to sunlight affect the population structure of C. fluminea, as well as analysing possible ecological implications. This study was based on the hypothesis that the influence of the above-mentioned factors alters the environmental scenario and modulates population aspects (e.g. density, length and distribution) of this species.

\section{Material and Methods}

\subsection{Study site}

The reservoir of Furnas Hydroelectric Power Station (HPS) is located in the southern region of Minas Gerais state. It was dammed in 1962 and is formed by rivers Grande and Sapucaí (higher Paraná basin) and other small tributaries (Figure 1). It has flooded an area of $1,440 \mathrm{~km}^{2}$, a perimeter of $3,500 \mathrm{~km}$, a volume of $20.86 \mathrm{x}$ $10^{6} \mathrm{~m}^{3}$, length of $250 \mathrm{~km}$, maximum depth of $100 \mathrm{~m}$ and average level of the water column of 15.5 metres. It is one of the largest reservoirs in the state and one of the most important in the country (Azevedo-Santos et al., 2011; Paschoal et al., 2013b).

This study was conducted at the margins of a stretch of river Sapucaí, inserted in the Furnas HPS reservoir, near the city of Carmo do Rio Claro (Minas Gerais, Brazil; Figure 1). This area is characterized by high water column fluctuation levels (Figures 2, 3), sandy-clay sediment, pebbles and boulders along the margins, a predominance of Brachiaria sp. (Trin.) Griseb. beside the margins and Eichhornia azurea (Kunth) ten metres away from the margin (Paschoal et al., 2013a).

\subsection{Sampling procedure}

Samplings were carried out twice, on October 2011 and on August 2012. In situ measurements occurred between 8:00 a.m. and 3:00 p.m.

National Water Agency (Agência Nacional de Águas) (ANA, 2013) and the National Power System Operator (Operador Nacional do Sistema Elétrico) (ONS, 2013) provided data about water column levels and accumulated precipitation from January 2007 to December 2012 in the 


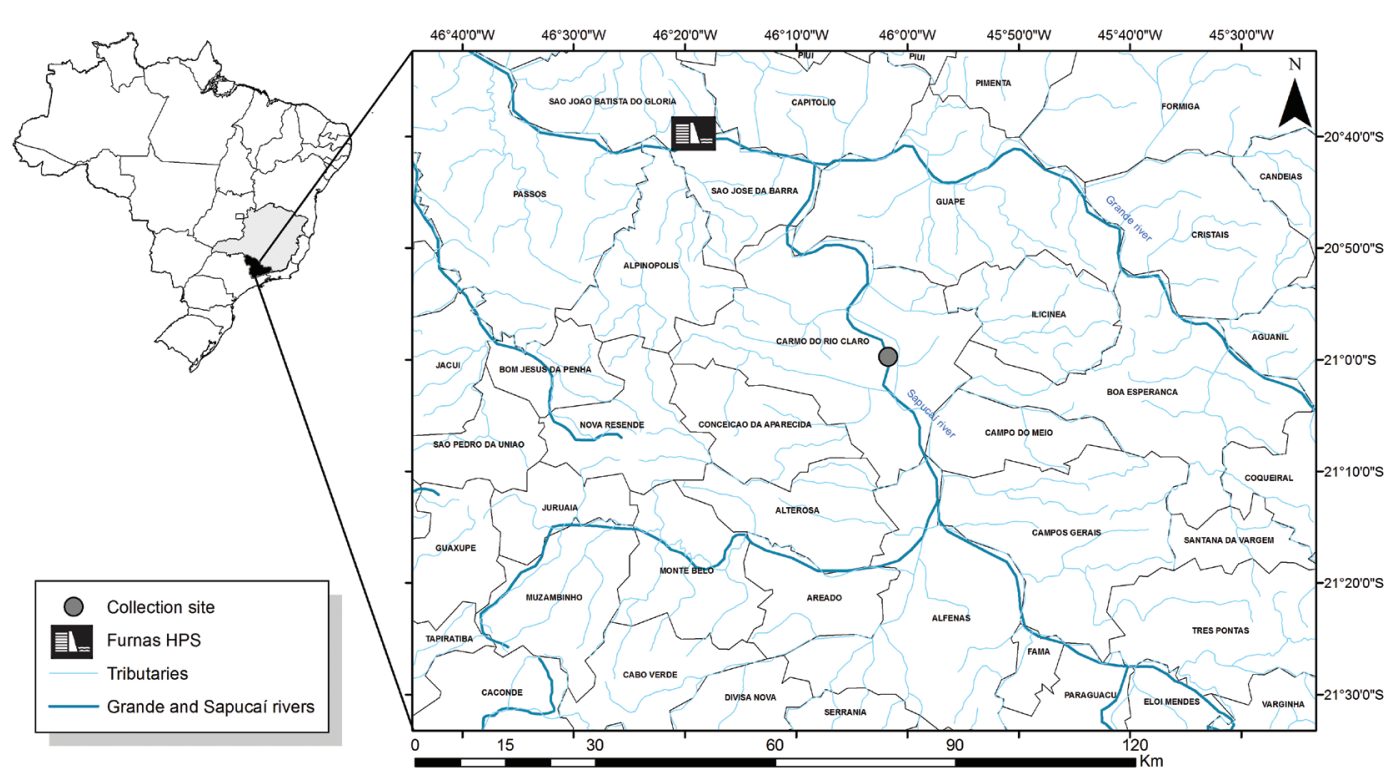

Figure 1. Map showing sampling site location.
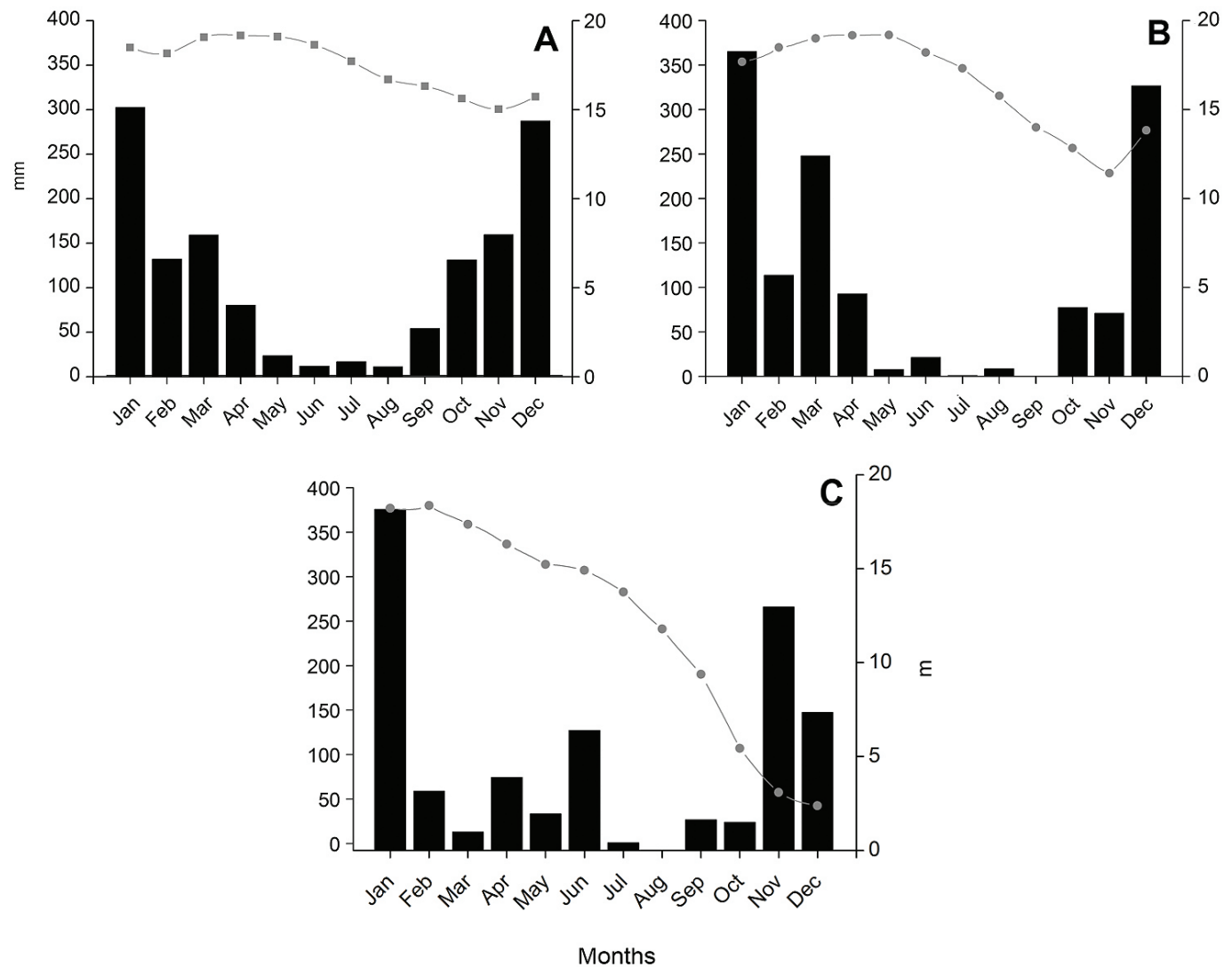

- Precipitation $(\mathrm{mm}) \bigcirc$ Height $(\mathrm{m})$

Figure 2. A. Accumulated precipitation and water column mean values from January 2007 to December 2012 for the portion of river Sapucaí inserted in Furnas HPS reservoir. B. Accumulated precipitation and water column height values for 2011. C. Accumulated precipitation and water column values for 2012 . 

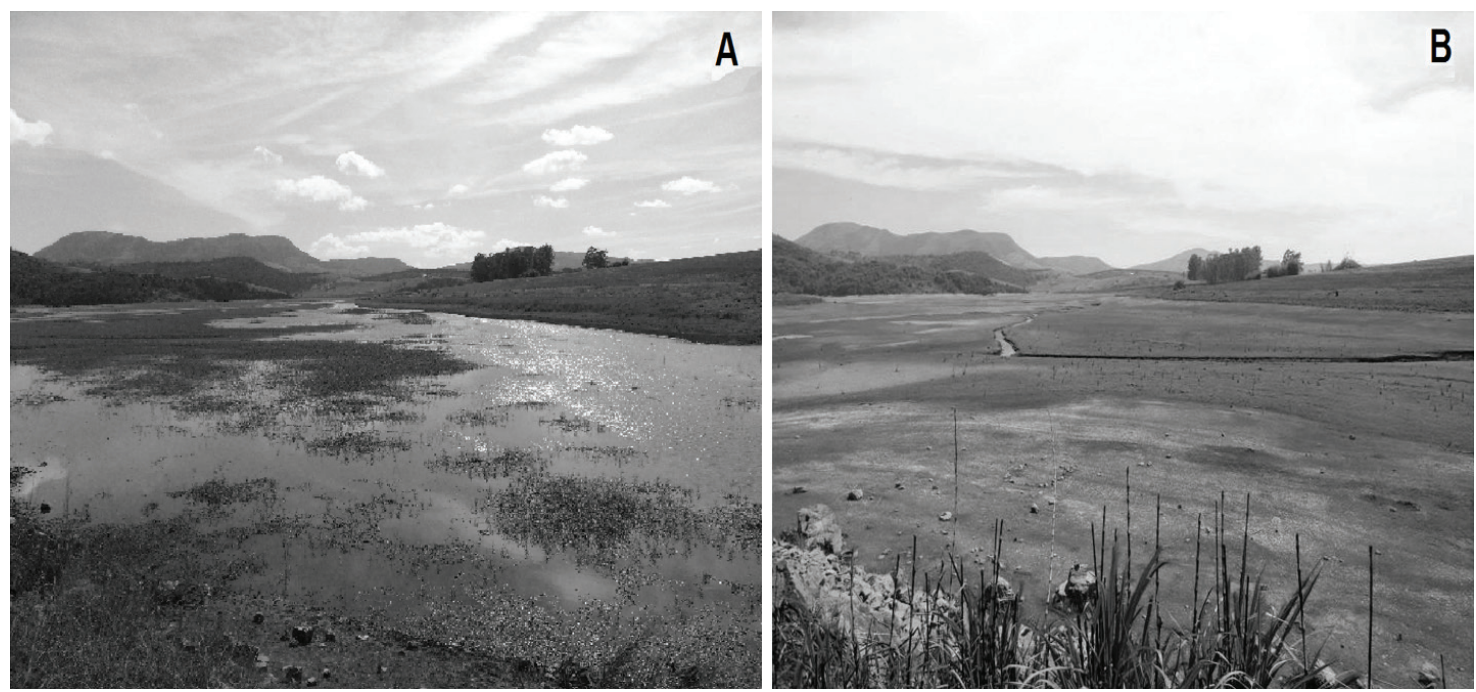

Figure 3. Variation of the water column in sampling site. A. Flooded area at normal periods. B. Exposed area due the absence of water and exposure to sunlight.

sampled stretch of the Furnas HPS reservoir. Monthly average values of these variables were calculated, showing that from June to October the water column level of the reservoir tends to decline due to low precipitation levels in the previous months (May to September), until it reaches its maximum level in November (Figure 2a). However, unlike 2011 (Figures 2b, 3a), in 2012, December was the month with the lowest water column level due to a prolonged drought in the south-eastern region of Brazil (Figures 2c, 3b)

Population density (individuals $/ \mathrm{m}^{2}$ ), mean shell length ( $L$ - following Araujo et al., 1993) and spatial distribution of C. fluminea for each year were estimated using 51 quadrats with an area of $0.0625 \mathrm{~m}^{2}$, based on parameters established by Paschoal et al. (2013a).

Considering the significant variation of the water column throughout the year in this area (Figures 2,3), a fixed-point (i.e. margin) was determined to establish the population aspects of $C$. fluminea at Furnas HPS (Figure 4). The quadrats were arranged randomly in three horizontal transects of $50 \mathrm{~m}$ on the left margin of river Sapucaí, where 17 quadrats were sampled for each transect. The first transect was located at the margin of the reservoir ( $0 \mathrm{~m}$ - fixed-point), the second was placed ten metres away from margin $(10 \mathrm{~m})$ and the third was 20 metres away $(20 \mathrm{~m})$ (Figure 4).

In measurements during both years, this area was exposed (i.e. absence of water) to sunlight for a considerable amount of time (4-5 months) due to the shallow depth of the littoral zone (ranging from 0 to $100 \mathrm{~cm}$ ), favouring the desiccation in molluscs (Paschoal, personal observation).

In each sampled transect $(0,10$ and $20 \mathrm{~m})$, all dead shells (i.e. without soft parts, lost during decomposition) were identified, counted and measured with a calliper $(0.1 \mathrm{~mm})$. Shell fragments and buried individuals that could not be identified were disregarded.

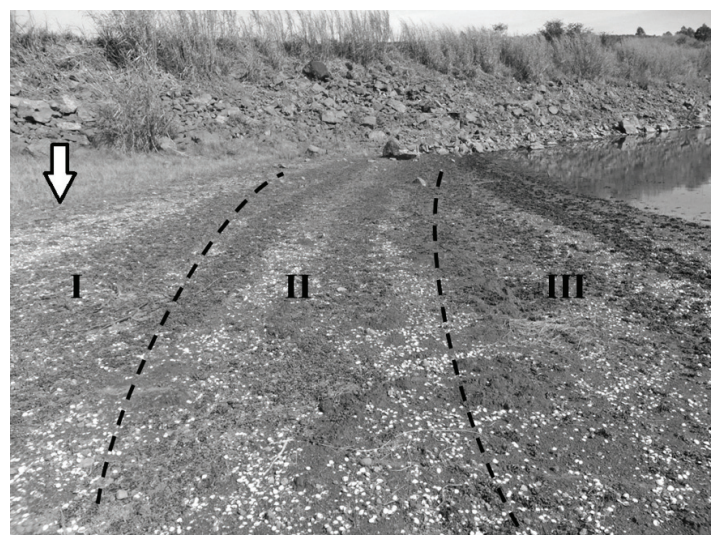

Figure 4. Corbicula fluminea (Müller, 1774). Horizontal transects showing the massive mortalities with a great accumulation of dead shells (white dots) at Furnas HPS reservoir. White arrow indicates the fixed-point at the margin. I: margin $(0 \mathrm{~m})$, II: ten metres after the margin (10 m), III: 20 metres from the margin $(20 \mathrm{~m})$.

Permissions were granted by the ICMBio/SISBIO (SISBIO \#36210-1). Voucher lots were sent to the Museu de Zoologia da Universidade de São Paulo (MZUSP), catalogued under numbers MZUSP 108053 and 108671.

\subsection{Data analysis}

A two-way analysis of variance (ANOVA) associated to the multiple comparison Tukey test were used to determine whether density and shell length $(L)$ of individuals differed between the different transect distances and during the two sampling years. Interaction between these two factors was also tested. Original data of average density and $L$ were transformed into base-10 logarithms.

The distribution pattern of $C$. fluminea was determined using the Morisita index $\left(I_{M}\right)$ (Krebs, 1989). Distribution of 
individuals is considered random when $I_{M}=1$, aggregate when $I_{M}>1$ and uniform when $I_{M}<1$. Differences between $I_{M}$ values for each year were compared using the $t$-test.

The relation between density and $L$ of the species and distance of transects from the margin were evaluated using linear regression and the Pearson's correlation coefficient.

All calculations and statistical analyses were done with Statistica 8.0 (StatSoft Inc, 2007) software.

\section{Results}

On both samplings, four mollusc species were recorded, with a predominance of Corbicula fluminea in both years (N: 1,122 [2011] and 1,118 [2012]). With the exception of Melanoides tuberculata (Müller, 1774) (N: 14 [2011] and 20 [2012]); only two species, Anodontites trapesialis (Lamarck, 1819) and Biomphalaria tenagophila (Orbigny, $1835)$, were found in 2011, in very small quantities (N: 4 and 1 , respectively).

In 2011, average densities of $C$. fluminea along the margin were $216(0 \mathrm{~m}), 360(10 \mathrm{~m})$ and $491(20 \mathrm{~m}) \mathrm{ind} /$ $\mathrm{m}^{2}$, and, in 2012, $160(0 \mathrm{~m}), 280(10 \mathrm{~m})$ and $630(20 \mathrm{~m})$ $\mathrm{ind} / \mathrm{m}^{2}$ (Figure 5). There was no significant difference between the years $(F=0.11 ; p=0.74)$, although there were significant differences between abundance of individuals in relation to the different transect distances $(F=45.24$; $p<0.01)$. There was no significant interaction between these two factors $(F=2.7 ; p=0.07)$.

We observed a tendency of individual density increase in both years as we moved away from the margin $\left(r^{2}=0.99\right.$ [2011], 0.93 [2012]; $p<0.001)$. Regardless of the absence of significant differences between $I_{M}$ values for the two years $(t=1.65 ; p=0.17)$, the population presented a tendency for aggregation in 2011 during the entire sampled river stretch. In 2012, however, the individuals that inhabited the margin $(0 \mathrm{~m})$ and proximity $(10 \mathrm{~m})$ were randomly distributed (Figure 5).
Mean lengths recorded for $C$. fluminea along the margin in 2011 were $15.88(0 \mathrm{~m}), 17.31(10 \mathrm{~m})$ and $18.72(20 \mathrm{~m}) \mathrm{mm}$, and in 2012, they were $21.75(0 \mathrm{~m})$, $21.36(10 \mathrm{~m})$ and $20.49(20 \mathrm{~m}) \mathrm{mm}$ (Figure 6$)$. There was a significant difference between the years $(F=184$; $p<0.001)$ and between transects distances $(F=4.7$; $p=0.01)$, with significant interaction between these two factors $(F=18.2 ; p<0.001)$. It was also possible to observe that the population of 2011 showed a tendency to increase in size as the individuals distanced themselves from the margin $\left(\mathrm{r}^{2}: 0.98 ; p<0.001\right)$, although an inverted pattern was registered in $2012\left(r^{2}:-0.99 ; p<0.001\right)$ (Figure 6).

\section{Discussion}

Among other groups, freshwater bivalves are responsible for a wide range of complex ecological roles in the aquatic biota, namely serving as food source for beings of superior trophic levels, and by parasitizing fish and other invertebrates, reducing water turbidity, acting in nutrient (re)cycling and creating habitats for other benthic species (Santos et al., 2012; Sousa et al., 2012). It is therefore extremely important to evaluate the effects of density and biomass changes in bivalve populations in these ecosystems when they are exposed to different environmental effects, such as desiccation, flooding, drought, etc. In addition to these environmental alterations, bivalves, especially invasive species in general, can act as ecosystem bioengineers due to their capacity to modify the abiotic environment by altering its chemical and/or physical structures. Consequently, these beings eventually affect other components of the biota and their interactions, and several other ecological processes in the ecosystems in which they live (Ricciardi, 2003; Darrigran and Damborenea, 2011).

Within a given ecosystem, the concept of bioengineering is related to certain ecological and evolutive parameters
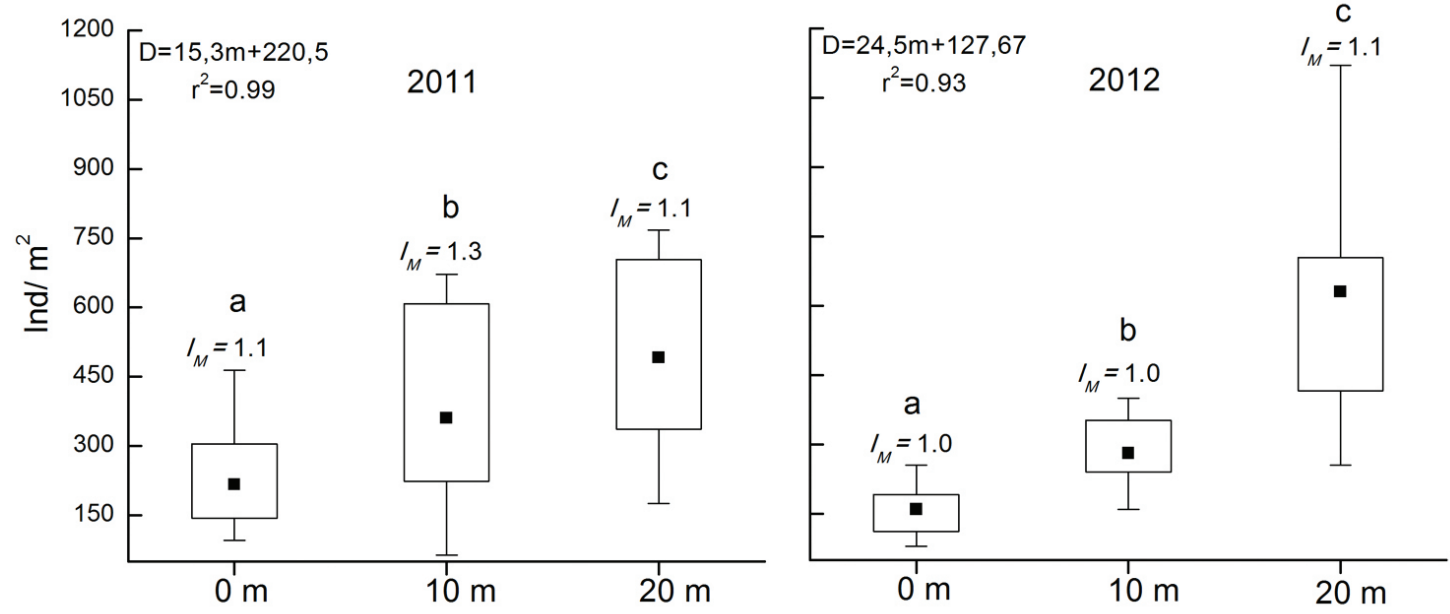

Figure 5. Corbicula fluminea (Müller, 1774). Minimum, maximum (whiskers) and mean (black square) density values of bivalve die-offs for each site. Different letters are significantly different in pairwise comparisons. D: density, $I_{M}$ : Morisita index, $\mathrm{r}^{2}$ : determination coefficient. 
(Jones et al., 1994), which should be particularly known and established for possible environmental management and estimates of impacts on the biota (Ricciardi, 2003; Gutiérrez and Jones, 2008). In particular, the invasive bivalve Corbicula fluminea is a bioengineer of ecosystems (Sousa et al., 2009).

In Brazil, C. fluminea is usually found in lotic environments, but when it occupies lentic environments (e.g. lakes and reservoirs), it usually inhabits well-oxygenated margin areas (Mc Mahon, 1983; Darrigran, 1992), with slight sloping and preferably sandy substrate (Santos et al., 2012). These characteristics were also recorded in the the studied area. In 2007, Paschoal et al. (2013b) observed the occurrence of $C$. fluminea for the first time in the reservoir of Furnas HPS. The same authors also recorded the density of these species and the depth where they were found in that area, and showed similar results to other studies conducted in southeastern Brazil (Table 1).

Biological invasions are usually registered when the invasive species has already established itself (Belz et al., 2012). Santos et al. (2012) stated that after the invasion of C. fluminea and other non-native species of molluscs in several Brazilian hydrographical basins, a drastic reduction of native benthonic mollusc populations incurred. This fact was also observed in this study. In addition to being the most representative mollusc species sampled in the area (98\% of sampled individuals), specimens of the native genera Anodontites (Bruguière, 1792) and Biomphalaria (Preston, 1910) were only recorded in 2011, in small quantities. This observation is supported by a recent extensive survey conducted by Andrade et al. (2013), in which authors recorded ten species of limnic molluscs in Grande River - another river running along Furnas HPS reservoir (Figure 1). In such areas the density of $C$. fluminea was low or absent.

The potential alterations in the macrozoobenthic community, especially native bivalve populations, can be explained by a synergy of two factors: (I) environmental impacts resulting from natural causes, such as a heat waves, desiccation, drought, etc. and (II) synergic effects caused by high densities and mortality of $C$. fluminea. In this context, the population of $C$. fluminea would rapidly recover from the impact due to its invasive species characteristics (e.g. increased adaptation and reproductive capacity and greater

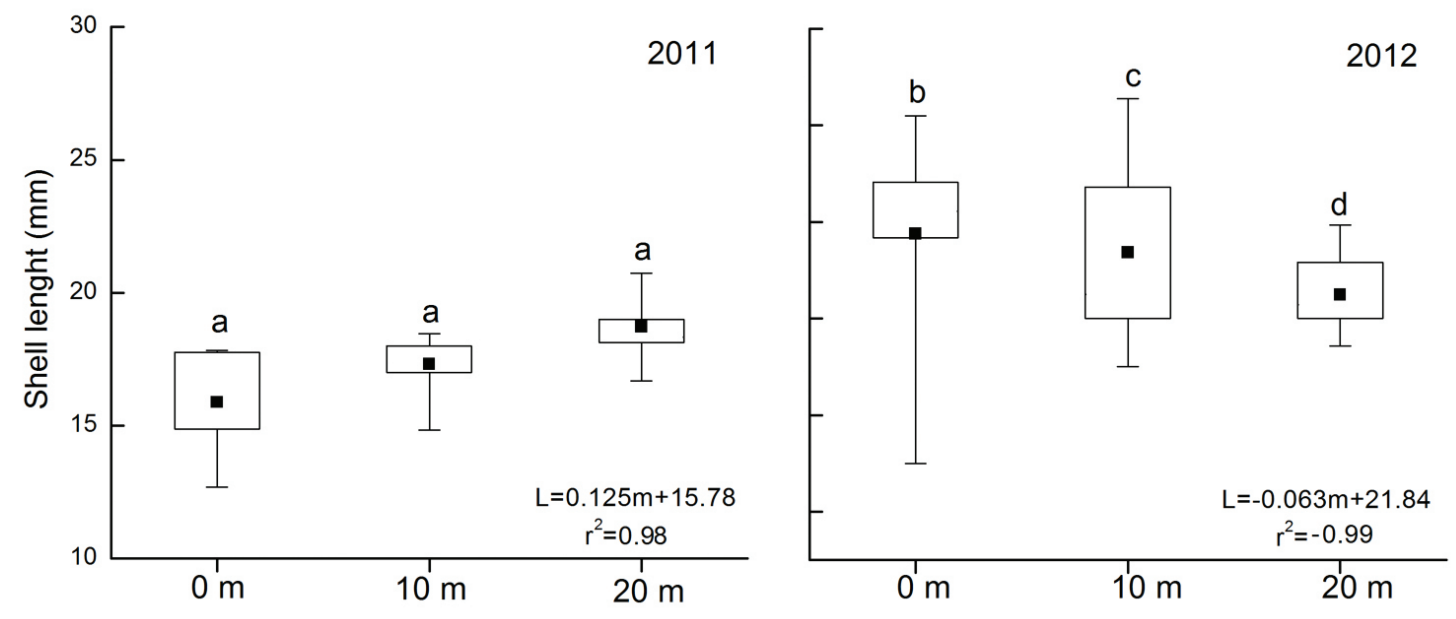

Figure 6. Corbicula fluminea (Müller, 1774). Minimum, maximum (whiskers) and mean (black square) shell length values of bivalve die-offs for each site. Different letters are significantly different in pairwise comparisons. L: shell length, $\mathrm{r}^{2}$ : determination coefficient.

Table 1. Corbicula fluminea (Muller, 1774). Comparisons of densities, depths from which specimens were collected and samplers (area) used between studies from different reservoirs at southeast Brazil.

\begin{tabular}{lcccl}
\hline \multicolumn{1}{c}{ Sites } & Sampler (área - $\left.\mathbf{m}^{2}\right)$ & $\begin{array}{c}\text { Density } \overline{\boldsymbol{X}} \\
(\mathbf{m i n}-\mathbf{m a x})\end{array}$ & Depth (m) & \multicolumn{1}{c}{ Authors } \\
\hline Furnas (MG) & $\begin{array}{l}\text { Modified Peterson-type } \\
\text { sampler (0.035) }\end{array}$ & $295(19-1.350)$ & $9-27$ & Paschoal et al. (2013b) \\
Amador Aguiar I (MG) & Van Veen grab (0.034) & $(48-293)$ & ni $_{*}$ & Maroneze et al. (2011) \\
Barra Bonita (SP) & Van Veen grab (0.034) & 25 & $5-7$ & Suriani et al. (2007) \\
Bariri (SP) & Van Veen grab (0.034) & $(10-1.499)$ & $1-9$ & Suriani et al. (2007) \\
Ibitinga (SP) & Van Veen grab (0.034) & $(50-650)$ & $1-10$ & Suriani et al. (2007) \\
Bariri (SP) & Van Veen grab (0.038) & $(147-295)$ & $0-12$ & Pamplin (2004) \\
\hline
\end{tabular}

\footnotetext{
*ni: data not informed.
} 
resilience) (Darrigran et al., 2007), quickly reaching the same density and biomass it possessed prior to the impact that occurred on the biota (Ilarri et al., 2011). According to Ricciardi (2003), native species do not have the same capacity to overcome, adapt and resist drastic disturbances and/or changes in aquatic environments, and cannot repel increments in the invasive biota. If this was the case, they would shift from their niche and/or natural environment and there would consequently be greater non-native population growth.

The significant differences recorded between the distances from the margins and in densities of $C$. fluminea in this study show the pronounced temporal variability of physical conditions of these transitional environments (e.g. extreme seasonal events with temperature changes, aerial exposure, desiccation and oxygen deficit during specific periods). These conditions not only affect density and spatial distribution of organisms, but also their diversity (Montecinos et al., 2009). In this study, greater environmental stability (i.e. less aerial exposure time due to greater distance from the margin) was observed at 20 metres from the margin due to increased density of $C$. fluminea.

Albarran-Melze (2009) and Santos et al. (2012) state that aggregated distribution is the most commonly observed spatial distribution among molluscs, which was also observed during 2011 in this study. This kind of spatial arrangement is based on environmental heterogeneity, in which specimens group in microenvironmental areas that are more adequate to their lifestyle (Begon et al., 2006). On the other hand, the random spatial arrangement registered in 2012 indicates that the environment is more homogenous, where the probability of finding a given individual is the same for all points in a given space (Southwood, 1995). The entire sampled environment up to 20 metres from the margin presented a similar response to the impact caused by a desiccation period that the environment was experiencing, so all individuals had the same probability of being collected in each point of the area.

According to García et al. (2003), the factors that influence density and frequency distribution of bivalve length are mainly size and sorting of sediment grains, declivity of locations and organic content of sediment. During moments of hydric stress, as observed in this study, these environmental factors are the first to be altered due to shortage of water (Paschoal, unpublished data; for this statement see the Figure 3). However, C. fluminea, as is the case in other invasive species, is opportunistic. According to Darrigran et al. (2003) in the case of Limnoperna fortunei Dunker, 1857 (another invasive bivalve species), the fact that it presents the characteristics of invasive species makes it difficult to relate the reproductive patterns with environmental variables and characterise the different modifications of its life cycle. This is also true for the specific case of $C$. fluminea, when we consider its distribution by shell length in the studied area. Statistically significant differences of length in the populations in relation to the spatial variable (distance from margin), the temporal variable and interaction between both factors may be, in synthesis, a consequence of the adaptive and reproductive capacity of $C$. fluminea.

When these temporal events are associated, they cause overall alterations in the malacofauna and also modulate certain population aspects of invasive species in lentic environments, proving the initial hypothesis. Future studies addressing temporal changes in transitional environment patterns are extremely important, considering that freshwater bivalves are faunal group with several endangered representatives, with many representatives responsible for serious environmental and economic problems in reservoirs and hydroelectric plants around the world (Amaral et al., 2008). The results presented in this study help partially fill the gap represented by the lack of information on the influence of temporal water-level declines in reservoirs, together with sunlight exposure for $C$. fluminea, creating a basis for future studies and research related to management and control of this non-native species.

\section{Acknowledgements}

We thank ACC. Francez for her help in the field, FL. Carvalho for his photos, VM. Azevedo-Santos for his help in the field and comments which significantly improved this paper and DC. Cavallari for the English tips, as well as FCNyM (UNLP) and CONICET (PIP 1017). The first author thanks the scholarship provided by Coordenadoria de Aperfeiçoamento de Pessoal de Nível Superior (CAPES) and Universidade Estadual Paulista (UNESP/Rio Claro PPG Ciências Biológicas/Zoologia).

\section{References}

Agência Nacional de Águas - ANA., 2013. Sistema Nacional de Informações sobre Recursos Hídricos. ANA. Available from: $<$ http://portalsnirh.ana.gov.br>. Access in: 12 Jan. 2013.

ALBARRAN-MELZE, N., RANGEL-RUIZ, L. and GAMBOAAGUILAR, J., 2009. Distribución y abundancia de Melanoides tuberculata (Gastropoda: Thiaridae) en la Reserva de la Biosfera Pantanos de Centla, Tabasco, México. Acta Zoológica Mexicana, vol. 25 , no. 1 , p. 93-104.

AMARAL, ACZ., RIBEIRO, CV., MANSUR, MCD., SANTOS, SB., AVELAR, WEP., MATTHEWS-CASCON, H., LEITE, FPP., MELO, GAS., COELHO, PA., BUCKUP, GB., BUCKUP, L.,VENTURA, CRR. and TIAGO, CG., 2008. A situação de ameaça dos invertebrados aquáticos no Brasil. In MACHADO, ABM., DRUMMOND, GM. and PAGLIA, AP. (Eds.). Livro vermelho da fauna brasileira ameaçada de extinção.Brasília: Ministério do Meio Ambiente. p. 157-301.

ANDRADE, DP., PASCHOAL, LRP. and CAVALLARI, DC., 2013. Levantamento preliminar da malacofauna límnica na área de influência do reservatório da Usina Hidrelétrica de Mascarenhas de Morais, Minas Gerais. In XX Congresso de Iniciação Científica da UFSCar, 2013. São Carlos. São Carlos: Universidade Federal de São Carlos.

ANDRADE, DP., PASCHOAL, LRP., SÁ, OR. and FRANÇA, N., 2012. Water quality assessment of fifth-order tributaries of the reservoir at the Marechal Mascarenhas de Morais Hydroelectric Power Station in the Rio Grande watershed (State of Minas 
Gerais, Brazil). Acta Limnologica Brasiliensia, vol. 24, no. 3, p. 326-337. http://dx.doi.org/10.1590/S2179-975X2013005000002.

ARAUJO, R., MORENO, D. and RAMOS, MA., 1993. The Asiatic clam Corbicula fluminea (Müller, 1774) (Bivalvia: Corbiculidae) in Europe. American Malacological Bulletin, vol. 10, p. 39-49.

AZEVEDO-SANTOS, VM., RIGOLIN-SÁ, O. and PELICICE, FM., 2011. Growing, losing or introducing? Cage aquaculture as a vector for the introduction of non-native fish in Furnas Reservoir, Minas Gerais, Brazil. Neotropical Ichthyology, vol. 9, no. 4, p. 915-919. http://dx.doi.org/10.1590/S1679-62252011000400024.

BELZ, CE., DARRIGRAN, G., MÄDER NETTO, OS., BOEGER, WA. and RIBEIRO JUNIOR, PJ., 2012. Analysis of Dispersion Vectors in Inland Waters: The Case of the Invading Bivalves in South America. Journal of Shellfish Research, vol. 31, no. 3, p. 777-784. http://dx.doi.org/10.2983/035.031.0322.

BEGON, M., TOWNSEND, CR. and HARPER, JL., 2006. Ecology: from individuals to ecosystems. Oxford: Blackwell Publishing. $738 \mathrm{p}$.

DARRIGRAN, G., 1992. Nuevos datos acerca de la distribución de las especies del género Corbicula (Bivalvia, Sphaeriacea) en el área del Río de la Plata, República Argentina. Notas Museo La Plata, vol. 21, p. 143-148.

DARRIGRAN, G., 1999. Longitudinal distribution of molluscan communities in the Río de la Plata estuary as indicators of environmental conditions. Malacological Review supl. Freshwater Mollusca, vol. 8, p. 1-12.

DARRIGRAN, G. and LOPEZ ARMENGOL, MF., 1998. Composition, structure and distribution of malacofauna living on a hard substrate at the Argentinian shore of Río de la Plata, Argentina. Gayana Zoologica, vol. 62, no. 1, p. 79-89.

DARRIGRAN, G.; DAMBORENEA, C.; PENCHASZADEH, P. and TARABORELLI, C., 2003. Adjustment of Limnoperna fortunei (Bivalvia: Mytilidae) after ten years of invasion in the Americas. Journal of Shellfish Research, vol. 22, n. 1, p. 141-146.

DARRIGRAN, G. and LAGRECA, M., 2005. Moluscos Litorales del Estuario del Río de la Plata. Argentina: ProBiota. 41 p. Serie Técnica y Didactica, no. 8.

DARRIGRAN, G., DAMBORENEA, C. and GRECO, N., 2007. Freshwater invasive bivalves in man-made environments: A case study of larvae biology of Limnoperna fortunei in a Hydroelectric Power Plant in South America. AMBIO: A Journal of the Human Environment, vol. 36, no. 7, p. 575-579.

DARRIGRAN, G. and DAMBORENEA, C., 2011. Ecosystem engineering impact of Limnoperna fortunei in South America. Zoological Science, vol. 28, no. 1, p. 1-7. http://dx.doi.org/10.2108/ zsj.28.1. PMid:21186940

FURLEY, TH. and OLIVEIRA FILHO, AC., 2000. Biomonitoring of heavy metals and organo-clorinated compounds in a pulp mill effluent using introduced mussels. Aquatic Ecosystem Health \& Management, vol. 3, p. 499-507.

GARCÍA, N., PRIETO, A., ALZOLA, R. and LODEIROS, C., 2003. Crecimiento y distribución de tallas de Donax denticulatus (Mollusca: Donacidae) en Playa Brava, Península de Araya, Estado de Sucre, Venezuela. Revista Cientifica, FCV-LUZ, vol. 13, no. 6, p. 464-470.

GUTIÉRREZ, JL. and JONES, CG., 2008. Ecosystem Engineers. Encyclopedia of Life Sciences (ELS), p. 1-6.
ILARRI, M., ANTUNES, C., GUILHERMINO, L. and SOUSA, R., 2011. Massive mortality of the Asiam Clam Corbicula fluminea in a highly invaded area. Biological Invasions, vol. 13, no. 2, p. 277-280. http://dx.doi.org/10.1007/s10530-010-9833-5.

JONES, CG., LAWTON, JH. and SHACHAK, M., 1994. Organisms as ecosystem engineers. Oikos, vol. 69, no. 3, p. 373-386. http:// dx.doi.org/10.2307/3545850.

KREBS, CJ., 1989. Ecological Methodology. New York: Harper \& Row. 624 p.

MANSUR, MCD., SANTOS, CP., DARRIGAN, G., HEYDRICH, I., CALLIL, CT. and CARDOSO, FR., 2003. Primeiros dados quali-quantitativos do mexilhão-dourado, Limnoperna fortunei (Dunker), no Delta do Jacuí, no Lago Guaíba e na Laguna dos Patos, Rio Grande do Sul, Brasil e alguns aspectos de sua invasão no novo ambiente. Revista Brasileira de Zoologia $=$ Zoologia (Curitiba), vol. 20, no. 1, p. 75-84. http://dx.doi.org/10.1590/ S0101-81752003000100009.

MARONEZE, DM., COSCARELLI, D., VIDIGAL, THA. and CALLISTO, M., 2011. First record of Corbicula fluminea (Müller, 1774) in the drainage basin of the Araguari River, Minas Gerais, Brazil. Brazilian journal of biology $=$ Revista brasleira de biologia, vol. 71, no. 1, p. 221-222. http://dx.doi.org/10.1590/ S1519-69842011000100033. PMid:21437423

MC MAHON, R., 1983. Ecology of an invasive pest bivalve, Corbicula. In WILBUR, KM. (Ed.). The Mollusca. New York: Academic Press. p. 505-561.

MONTECINOS, L., CISTERNA, J., CACERES, C. and SALDIAS, G., 2009. Equilibrio ácido-base durante la exposición aérea en el molusco bivalvo Perumytilus purpuratus (Lamarck, 1819) (Bivalvia: Mytilidae). Revista de Biología Marina y Oceanografia, vol. 44 , no. 1, p. 181-187.

Operador Nacional do Sistema Elétrico - ONS, 2013. Histórico da Operação. ONS. Available from: $<\mathrm{http}: / / \mathrm{http}: / / \mathrm{www}$.ons.org. br>. Access in: 12 Fev. 2013.

PAMPLIN, PAZ., 2004. Estudo comparativo da estrutura da comunidade bentônica de duas represas com diferenças no grau de eutrofização. São Carlos: Universidade Federal de São Carlos. 113 p. Tese de Doutorado em Ecologia e Recursos Naturais.

PASCHOAL, LRP., ANDRADE, DP. and DARRIGRAN, G., 2013a. Size comparison of quadrats in sample of non-native bivalve Corbicula fluminea (Müller, 1774) (Bivalvia: Corbiculidae). PanAmerican Journal of Aquatic Sciences, vol. 8, no. 4, p. 369-374.

PASCHOAL, LRP., STRIPARI., NL. and CARVALHO, K., 2013b. Estrutura da comunidade de macroinvertebrados bentônicos no reservatório da Usina Hidréletrica de Furnas/Minas Gerais - Brasil. In RIGOLIN-SÁ, O. (Org.). Bacia hidrográfica: Estudos do Rio Grande no Sudoeste de Minas Gerais- Brasil. Passos: Edifesp. p. $169-182$.

RICCIARDI, A., 2003. Predicting the impacts of an introduced species from its invasion history: an empirical approach applied to zebra mussel invasions. Freshwater Biology, vol. 48, no. 6, p. 972-981. http://dx.doi.org/10.1046/j.1365-2427.2003.01071.x.

SANTOS, SB., THIENGO, SC., FERNANDEZ, MA., MIYAHIRA, IC., GONÇALVES, ICB., XIMENES, RF., MANSUR, MCD. and PEREIRA, D., 2012. Espécies de moluscos límnicos invasores no Brasil. In MANSUR, MCD., SANTOS, CP., PEREIRA, D., PAZ, ICP., ZURITA, MLL., RODRIGUEZ, MTR., NEHRKE, MV. and BERGONCI, PEA. (Orgs.). Moluscos límnicos invasores no Brasil: biologia, prevenção e controle. Porto Alegre: Redes Editora. p. 25-50. 
SOUSA, R., GUTIÉRREZ, JL. and ALDRIDGE, DC., 2009. Non-indigenous invasive bivalves as ecosystem engineers. Biological Invasions, vol. 11, no. 10, p. 2367-2385. http://dx.doi. org/10.1007/s10530-009-9422-7.

SOUSA, R., VARANDAS, S., CORTES, R., TEIXEIRA, A., LOPES-LIMA, M., MACHADO, J. and GUILHERMINO, L., 2012. Massive die-offs of freshwater bivalves as resource pulses. Annales de Limnologie - International Journal of Limnology, vol. 48, no. 1, p. 105-112. http://dx.doi.org/10.1051/limn/2012003.

SOUTHWOOD, TR., 1995. Ecological Methods: With particular reference to the study of insect populations. London: Chapman \& Hall. 524 p.

STATSOFT INC., 2007. STATISTICA (data analysis software system). Software version 8.0. Available from: $<\mathrm{http} / / \mathrm{www}$. statsoft.com>. Access in: 09 Aug. 2012.
SURIANI, AL., FRANÇA, RS. and ROCHA, O., 2007. A malacofauna bentônica das represas do médio rio Tietê (São Paulo, Brasil) e uma avaliação ecológica das espécies exóticas invasoras, Melanoides tuberculata (Müller) e Corbicula fluminea (Müller). Revista Brasileira de Zoologia = Zoologia (Curitiba), vol. 24, no. 1, p. 21-32. http://dx.doi.org/10.1590/S0101-81752007000100003.

TUNDISI, JG., MATSUMURA-TUNDISI, T. and ABE, DS., 2008. The ecological dynamics of Barra Bonita (Tietê River, SP, Brazil) reservoir: implications for its biodiversity. Brazilian journal of biology $=$ Revista brasleira de biologia, vol. 68, suplemento 4, p. 1079-1098. http://dx.doi.org/10.1590/S151969842008000500015. PMid:19197478

VAUGHN, C., 2010. Biodiversity losses and ecosystem function in freshwaters: emerging conclusions and research directions. Bioscience, vol. 60, no. 1, p. 25-35. http://dx.doi.org/10.1525/ bio.2010.60.1.7. 